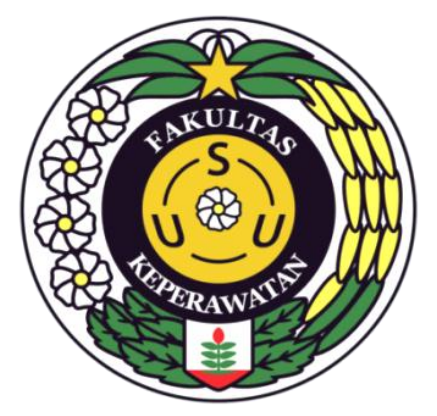

KAJIAN ILMIAH

PENGEMBANGAN SOFTSKILL PERAWAT MELALUI KEPEMIMPINAN

TRANSFORMASIONAL MENEJER KEPERAWATAN

DISUSUN OLEH :

ALISARJUNI PADANG/ 197046017

alisarjunipadang@gmail.com

PROGRAM STUDI MAGISTER ILMU KEPERAWATAN

FAKULTAS KEPERAWATAN

UNIVERSITAS SUMATERA UTARA

MEDAN

2019 


\title{
PENGEMBANGAN SOFTSKILL PERAWAT MELALUI KEPEMIMPINAN TRANSFORMASIONAL MENEJER KEPERAWATAN
}

\author{
ALISARJUNI PADANG/ 197046017 \\ alisarjunipadang@gmail.com
}

\begin{abstract}
Abstrak
Latar Belakang : Softskill adalah keterampilan kecakapan hidup baik untuk diri sendiri, berkelompok atau bermasyarakat yaitu berupa keterampilan dalam berhubungan dengan orang lain (interpersonal skill) maupun keterampilan dalam mengatur dirinya sendiri (intra personal skill) agar mampu mengembangkan produktifitas kerja secara maksimal, sedangkan Kepemimpinan transformasional merupakan kepemimpinan yang dapat diterapkan dengan karakteristik kharismatik, pengaruh idealis, motivasi inspirasional, stimulasi intelektual, serta konsiderasi individu. Tujuan : Penelitian ini bertujuan untuk mengidentifikasi kepemimpinan Transformasional kepala ruang terhadap pengembangan kemampuan softskill dari perawat pelaksana. Metode : Metode dalam penelitian ini adalah dengan menggunakan kajian pustaka, yang berkaitan dengan pengembangan soft skill perawat melalui kepemimpinan transformasional, dimana peneliti mengumpulkan beberapa jurnal kemudian melakukan pembanding. Hasil : Hasil ulasan literatur menunjukan bahwa peningkatan softskill sangat di pengaruhi oleh kepemimpinan transpormasional menejer keperawatan.
\end{abstract}

Kata kunci : kepemimpinan Transformasional, softskill, menejer 


\section{A. Latar Belakang}

Perawat adalah seseorang yang memberikan pelayanan kesehatan (care provider) secara profesional, dimana pelayanan tersebut berbentuk pelayanan biologis, psikologis sosial, spiritual yang ditujukan kepada individu, keluarga dan masyarakat. Perawat diharapkan memiliki kompetensi sebagai perawat profesional, baik berupa hard skill maupun soft skill.Soft skill merupakan salah satu keterampilan yang harus di miliki oleh setiap orang terutama bagi perawat. Soft skill diperlukan untuk mendukung hard skill atau keterampilan teknis yang telah didapatkan oleh para perawat saat mengikuti pendidikan. Beberapa hal termasuk dalam soft skill perawat adalah kemampuan beradaptasi, kemampuan berkomunikasi, kerjasama, memecahkan masalah, percaya diri, disiplin, teliti (Hartiti, 2012). Dapat disimpulkan bahwa kemampuan soft skill sangat diperlukan bagi dunia kerja, oleh karena keberhasilan seseorang tidak hanya ditentukan oleh kecerdasan intelektualnya saja akan tetapi justru kemampuan soft skill ini yang sangat berperan dalam mencapai prestasi sebuah pekerjaan.Agustian (2007), melaporkan hasil penelitian Belt (2001), pada responden majalah Six Sigmabahwa masalah soft skill yaitu : komunikasi sebesar 88\%, interpersonal $72 \%$, dankepemimpinan $56 \%$ yang dianggap paling penting, selain masalah teknikal dan analitikal atau hard skillhanya sebanyak $18 \%$, merupakan hal berikutnya yang dianggap penting. Bahkan setelah memasuki dunia kerja, pelatihan yang banyak dibutuhkan bukan bentuk pelatihan.

Pemimpin transformasional menciptakan suatu visi organisasi secara dinamis yang dibutuhkan untuk menciptakan inovasi. Pemimpin transformasional akan memulai segala sesuatu dengan visi, yang merupakan suatu pandangan dan harapan kedepan yang akan dicapai bersama dengan memadukan semua kekuatan, kemampuan dan keberadaan para pengikutnya. Mungkin saja bahwa sebuah visi ini dikembangkan oleh para pemimpin itu sendiri atau visi tersebut memang sudah ada secara kelembagaan yang sudah dibuat dirumuskan oleh para pendahulu sebelumnya dan masih selaras dengan perkembangan kebutuhan dan tuntutan pada saat sekarang (Hariyanti, 2011).

Kepemimpinan kepala ruangan sangat diperlukan untuk meningkatkan kinerja perawat pelaksana (Yusmanto, 2013). Kepala ruang sebagai seorang pemimpin yang memiliki pengaruh langsung dalam memperbaiki soft skill perawat pelaksana, diharapkan mampu menerapkan kepemimpinan yang positif, yaitu dengan 
kepemimpinan transformasional (Hartiti, 2013). Kepemimpinan transformasional ini merupakan gaya kepemimpinan yang relative masih baru, dengan penekanan pada aspek motivasi yang mendalam antara pimpinan dan bawahan.

Model Kepemimpinan Transformasional sudah mulai diterapkan dalam bidang keperawatan. Penerapan model ini dapat dilakukan pada kepala ruang yang merupakan manajer di dalam sebuah ruang perawatan pasien. Menurut Hartiti (2013) masih banyak didapatkan kepala ruang yang belum memiliki kemampuan transformasional ini seperti kharismatik, pengaruh idealis, motivasi inspirasi, stimulasi intelektual dalam pengelolaan kepemimpinannya, sehingga sangat perlu ditingkatkan pencapaiannya melalui kegiatan sehari-hari, yaitu pada interaksi sehari-hari antara kepala ruang dengan perawat pelaksana dalam menerapkan kepemimpinan transformasional ini.

Kepala ruang merupakan leader bagi perawat pelaksana di dalam ruang perawatan, sehingga dalam usaha untuk menjadi pemimpin pentransformasi (transforming leader) maka kepala ruang juga perlu untuk belajar bagaimana menjadikan timnya sebagai kekuatan yang positif. Pemimpin pentransformasi mencoba menimbulkan kesadaran para pengikut dengan mengarahkannya kepada cita-cita dan nilai-nilai moral yang lebih tinggi.

\section{B. Tujuan}

tujuan dari penelitian ini adalah untuk menganalisis pengembangan softskill perawat melalui kepemimpinan transformasional menejer keperawatan

\section{Metodologi}

Metode penelitian yang digunakan pada penelitian ini adalah dengan kajian pustaka terhadap beberapa jurnal yang berhubungan dengan peran pengembangan softskill perawat melalui kepemimpinan transformasional menejer keperawatan, dan beberapa jurnal yang digunakan dalam melakukan literature review adalah tahun 2011 sampai 2019 sebanyak 5 jurnal. 


\section{Hasil}

Hasil dari Beberapa Judul jurnal yang diambil dalam kajian ini adalah :

1. Peningkatan softskill mahasiswa perawat melalui Kepemimpinan transformasional dosen dalam Mengelola kelas di fikkes unimus

2. Peningkatan softskill perawat melalui kepemimpinan transformasional kepala ruang di rsi sultan agung semarang

3. Analisis peran kepemimpinan transformasional dalam mempertahankan Standar care of patient sesuai akreditasi jci Di rumah sakit awal bros tangerang

4. Pengaruh gaya kepemimpinan transformasional terhadap perawat dalam melakukan Terapi mindfullness

5. Upaya meningkatkan kemampuan kepemimpinan Transformasional kepala ruang Di rsi sultan agung semarang

\section{E. Pembahasan}

Dari penelitian Tri Hartiti dan Ernawati yang beerjudul Peningkatan softskill mahasiswa perawat melalui Kepemimpinan transformasional dosen dalam Mengelola kelas di fikkes unimus dengan metode penelitian deskriptife menyatakan bahwa :

1. Kepemimpinan transformasional dosen baik sebesar $54,2 \%$, dan yang kurang baik 45.8\%.. Komponenkemampuan transformasional yang paling banyak dan paling baik dimiliki oleh dosen adalahKharismatik, sedangkan yang paling kurang dimiliki oleh dosen adalah pengaruh idealis

2. Modul pelatihan kepemimpinan transformasional berupa rancangan kegiatan yang dapat dilaksanakan dosen untuk meningkatkan softskill mahasiswa

3. Dosen keperawatan mengalami peningkatan pemahaman mengenai pengelolaan kepemimpinan transformasional nya baik dikelas, dilaboratorium maupun diklinik sebesar $70 \%$

4. Dosen Keperawatan memiliki rencana pembaharuan model maupun metode mengajar melalui berbagai variasi yang berpusat pada mahasiswa (Student Center Learning) melalui komunikasi yang lebih intensif dan mendalam

Berdasarkan penelitian Tri Hartiti yang berjudul peningkatan softskill perawat melalui kepemimpinan transformasional kepala ruang di rsi sultan agung semarang 
dengan metode penelitian diskriptif korelasi dengan pendekatan crossectional menyatakan bahwa,

dari penelitian ini didapatkan 4 orang (22\%) kepala ruang yang telah memiliki kemampuan kepemimpinan transformasional baik, sedangkan 14 orang (78\%) belum baik, didapatkan 20 orang (25\%) perawat pelaksana yang telah memiliki softskill yang baik, sedangkan 60 orang $(75 \%)$ memiliki softskill yang kurang baik. Terdapat hubungan antara kepemimpinan transformasional kepala ruang dengan softskill perawat pelaksana dengan $\mathrm{p}=0,018$

Menurut penelitian Bertharia Ginting, Siti Komariah, Agustinus Bandur dengan judul analisis peran kepemimpinan transformasional dalam mempertahankan standar care of patient sesuai akreditasi jci di rumah sakit awal bros tangerang dengan metode tehnik analisis eksploratif mengemukakan bahwa usia menengah ke atas lebih mampu melakukan stimulasi intelektual terhadap staf yang dipimpinnya. Hal ini didikung dengan hasil penelitian Fauji \& Utami (2013)

Dari penelitian Ardinata, Agus susanto yang berjudul Pengaruh Gaya Kepemimpinan Transformasional terhadap Perawat dalam melakukan Terapi Mindfullness dengan metode pencarian yang menyeluruh terhadap semua jurnal (Comprehensive literature search). bahan literatur pada systematic review ini dilakukan pada periode rentang waktu antara tahun 2006 sampai dengan tahun 2016, dan mengidentifikasi menggunakan database journal elekronik dari sciencedirect, Ebsco, Google Scolar, dan portal Garuda. Hasil penelitian menunjukkan kepemimpinan transformasional, kepercayaan organisasi, kepercayaan pada atasan dan kepercayaan pada rekan kerja secara bersama-sama mampu menjadi predictor perilaku berbagi pengetahuan $(\mathrm{R} 2=0.264, \mathrm{p}<0.05)$. Lebih lanjut ditemukan bahwa kepemimpinan transformasional tidak signifikan dalam membentuk perilaku berbagi pengetahuan. Meskipun temuan ini terbilang kontradiktif, namun dapat diambil beberapa esensi penting yang justru dapat dikaji lebih dalam. Kepemimpinan transformasional sebagai salah satu model kepemimpinan motivasional memang memiliki nilai-nilai positif bagi pengembangan organisasi, namun keberhasilan pola kepemimpinan ini juga bergantung pada pengakuan dan kepercayaan dari para bawahan. Meskipun motivasi dan inspirasi selalu ditekankan dalam kepemimpinan transformasional, tetap saja harus terbentuk 
penerimaan dan kepercayan terlebih dahulu dari bawahan terhadap kapabilitas si pemimpin.

Berdasarkan Penelitian Milkhatun yang berjudul upaya meningkatkan kemampuan kepemimpinan transformasional kepala ruang di rsi sultan agung semarang dengan Metode pra eksperimen (pre-experimental designs) dengan bentuk one group pretest-posttes design menunjukkan bahwa ada peningkatan bermakna pada penerapan kepemimpinan transformasional sesudah mendapatkan pelatihan kepemimpinan transformasional ( $p$ value : 0.000). Kesimpulannya, pelatihan kepemimpinan transformasional berpengaruh terhadap penerapan kepemimpinan transformasional kepala ruang di Rumah Sakit Islam Sultan Agung Semarang.

\section{F. Kesimpulan}

Dari 5 jurnal yang dipilih, keseluruhanya dimasukkan dalam analisa review karena memiliki judul dan abstrak yang relevan.

Berdasarkan penelitian diatas menyatakan bahwa sangat dibutuhkanya pengembangan softskill keperawatan untuk meningkatkan mutu layanan keperawatan melalui kepemimpinan transpormasional kepala ruangan keperawatan.

\section{G. Rekomendasi}

Kepada seluruh menejer keperawatan ataupun pemimpin keperawatan agar memberikan kesempatan kepada bawahan dalam mengembangkan Softskill Dalam meningktkan mutu layanan asuhan keperawatan. 


\section{DAFTAR PUSTAKA}

Ahmad Fauzi Dodi 2007, Kepemimpinan Efektif, Restu Agung Jakarta

Ambarwati Sri DA 2003, Mengelola Perubahan Organisasional: Isu Peran Kepemimpinan Transformasional Dan Organisasi Pembelajaran Dalam Konteks Perubahan Jurnal Siasat Bisnis No. 8 Vol. 2 Desember 2003

Bass B.M. \& Avolio B.J. (2002). Multifactor Leadership Quesionare Sampler Set (2nd.ed).Redwood City, California : Mind Garden Inc

Bandur dkk (2014) analisis peran kepemimpinan transformasional dalam mempertahankan standar care of patient sesuai akreditasi jci di rumah sakit awal bros tangerang. Jurnal

Budiman Rasyid 2004, Pengaruh kepemimpinan transformasional pada organisasi citizenship dengan kecerdasan emosional karyawan PT Widia Duta Grafika

Burn J.M.(1978) Leadership Oxford.England Harper \& Row

Milkhatun ( 2016) upaya meningkatkan kemampuan kepemimpinan transformasional kepala ruang di rsi sultan agung semarang. Tesis

Elqorni Ahmad 2008 Kepemimpinan Abad 21, www.Ahmad Elqorni.co.id

Hartiti T (2012) peningkatan softskill perawat melalui kepemimpinan transformasional kepala ruang di rsi sultan agung semarang. Jurnal

Ismail G 2007 Soft Skill Untuk menjual diri di Dunia Kerja, Berita Universitas muhammadiyah yogyakarta 26 desember 2007

Jannsen L.T.(2004) Leadership Caracteristic of Hospital CEOS : Factor that Influence Leadership Style.Drake University Does Moines IA

Nursalam 2016. Metodologi Penelitian Ilmu Keperawatan, Edisi 4. Jakarta : Salemba Medika.

Susanto A (2019) Pengaruh Gaya Kepemimpinan Transformasional terhadap Perawat dalam melakukan Terapi Mindfullness. Jurnal

Simamora, R.H. (2016) Hubungan Mutu Pelayanan Keperawatan Dengan Tingkat Kepuasan Pasien Rawat Inap Di Rsud Pandan Kabupaten Tapanuli Tengah. jurnal

Tri Hartiti1 \& Ernawati (2017) peningkatan softskill mahasiswa perawat melalui kepemimpinan transformasional dosen dalam mengelola kelas di fikkes unimus. Jurnal 